\title{
Proteome-wide changes induced by the Hsp90 inhibitor, geldanamycin in anaplastic large cell lymphoma cells
}

\author{
Jonathan A. Schumacher ${ }^{1}$, David K. Crockett ${ }^{1}$, Kojo S. J. Elenitoba-Johnson ${ }^{2}$ \\ and Megan S. Lim $^{2}$ \\ ${ }^{1}$ Associated and Regional University Pathologists (ARUP), Institute for Clinical and Experimental Pathology, \\ Salt Lake City, UT, USA \\ ${ }^{2}$ Department of Pathology, University of Michigan Health Sciences Center, Ann Arbor, MI, USA
}

The molecular chaperone heat shock protein 90 (Hsp90) affects the function of many oncogenic signaling proteins including nucleophosmin-anaplastic lymphoma kinase (NPM-ALK) expressed in anaplastic large cell lymphoma (ALCL). While ALK-positive ALCL cells are sensitive to the Hsp90 inhibitor and the geldanamycin (GA) analog, 17-allylamino-17-demethoxygeldanamycin (17-AAG), the proteomic effects of these drugs on ALK-positive ALCL cells are unpublished. In this study, we investigated the cellular, biologic, and proteomic changes occurring in ALK-positive ALCL cells in response to GA treatment. GA induced $\mathrm{G}_{2} / \mathrm{M}$ cell cycle arrest and caspase-3mediated apoptosis. Furthermore, quantitative proteomic changes analyzed by cleavable isotopecoded affinity tag $^{\text {TM }}$-LC-MS/MS (cICAT ${ }^{\text {TM }}$-LC-MS/MS) identified 176 differentially expressed proteins. Out of these, 49 were upregulated 1.5 -fold or greater and 70 were downregulated 1.5 -fold or greater in GA-treated cells. Analysis of biological functions of differentially expressed proteins revealed diverse changes, including induction of proteins involved in the 26S proteasome as well as downregulation of proteins involved in signal transduction and protein and nucleic acid metabolism. Pathway analysis revealed changes in MAPK, WNT, NF- $\mathrm{B}$, TGF $\beta$, PPAR, and integrin signaling components. Our studies reveal some of the molecular and proteomic consequences of Hsp90 inhibition in ALK-positive ALCL cells and provide novel insights into the mechanisms of its diverse cellular effects.

\section{Keywords:}

ALCL / Geldanamycin / NPM-ALK
Received: February 1, 2007 Revised: March 20, 2007 Accepted: April 17, 2007
Correspondence: Dr. Megan S. Lim, University of Michigan, Department of Pathology, M5242 Medical Science Building 1, 1301 Catherine Road, Ann Arbor, MI 48105, USA

E-mail: meganlim@med.umich.edu

Fax: +1-734-936-2756

Abbreviations: 17-AAG, 17-allylamino-17-demethoxygeldanamycin; ALCL, anaplastic large cell lymphoma; cICAT $^{\text {TM }}$, cleavable isotope-coded affinity tag $^{\text {TM }}$; GA, geldanamycin; Hsp90, heat shock protein 90; JAK/STAT, janus kinase/signal transducer and activator of transcription; MAPK, mitogen-activated protein kinase; NF-кB, nuclear factor kappa B; NPM-ALK, nucleophosmin-anaplastic lymphoma kinase; PPAR, peroxisome proliferator-activated receptor; TGF $\beta$, transforming growth factor $\beta$

\section{Introduction}

Anaplastic large cell lymphoma (ALCL) is a type of nonHodgkin lymphoma that commonly harbors the $\mathrm{t}(2 ; 5)(\mathrm{p} 23 ; \mathrm{q} 35)$ chromosomal aberration, resulting in the expression of the $80 \mathrm{kDa}$ nucleophosmin-anaplastic lymphoma kinase (NPM-ALK) fusion oncoprotein [1-3]. Native NPM is a nucleolar phosphoprotein, whose functions include ribosomal RNA assembly, chaperone activities, and nuclease activity [4]. ALK is a $200 \mathrm{kDa}$ receptor tyrosine kinase [5] belonging to the insulin receptor superfamily [6]. An N-terminal oligomerization domain within NPM facilitates the dimerization of NPM-ALK, leading to autophos- 
phorylation and constitutive activation of the ALK tyrosine kinase [5]. Activated ALK induces multiple downstream signaling molecules including phospholipase $\mathrm{C} \gamma$ (PLC $\gamma$ ) [7], phosphatidylinositol-3-kinase (PI3K) [8]/RAC protein kinase (AKT) [9], Janus kinase 3 (JAK3) [10], signal transducer and activator of transcription 3 (STAT3) [11], and the nonreceptor protein kinase sarcoma (SRC) [12] which leads to enhanced cell proliferation, survival, and apoptosis inhibition [13].

The benzoquinone ansamycins geldanamycin (GA) and derivative, 17-allylamino-17-demethoxygeldanamycin (17AAG) elicit antitumor activity in a variety of cancer cell lines, including ALCL $[14,15]$. Heat shock protein 90 (Hsp90) has been identified as the primary target of GA [16]. Hsp90 is a highly conserved, ubiquitous molecular chaperone that is required for the stability and conformational maturation of a diverse group of client proteins, including components of signaling pathways exploited by cancer cells for survival and proliferation [17]. Hsp90 client proteins include receptor tyrosine kinases such as human epidermal growth factor receptor (EGFR) [18] family kinases, breakpoint cluster region-Abelson (BCR-ABL), and NPM-ALK; cytosolic signaling proteins such as AKT, v-raf-1 murine leukemia viral oncogene homolog 1 (RAF-1), and inhibitor of nuclear factor kappa (IKK) as well as cell cycle regulators including cyclindependent kinase 4 (cdk4), polo-like kinase 1 (PLK1), and survivin $[17,19,20]$. Inhibition of Hsp90 by ansamycins in ALK-positive ALCL cells results in downregulation of NPMALK protein kinase activity [14] leading to cellular apoptosis [15]. Clearly, there are multiple cellular targets of Hsp90, yet the comprehensive effects of Hsp90 inhibition in ALK-positive ALCL cells are unknown.

Recent developments in multidimensional LC techniques combined with MS/MS have enabled sensitive and high-throughput detection of low abundance proteins [21]. This technology combined with a cleavable isotope-coded affinity tag $\left(\mathrm{CICAT}^{\mathrm{TM}}\right)$ approach allows for the global quantitative analysis of proteins in complex mixtures [22]. In this study, we sought to assess the cellular, biologic, and quantitative proteomic changes occurring in ALK-positive ALCL cells in response to Hsp90 inhibition by GA. Our results demonstrate that $\mathrm{GA}$ induced $\mathrm{G}_{2} / \mathrm{M}$ cell cycle arrest and caspase-3-mediated apoptosis. Moreover, we identified 49 proteins that were upregulated 1.5 -fold or greater and 70 proteins downregulated 1.5-fold or greater in GA-treated cells. Importantly, we identified several proteins involved in diverse cellular functions, including signal transduction, DNA metabolism, nucleic acid and protein metabolism, cell growth and maintenance, and energy pathways. Some of the downregulated proteins are known to be involved in described signaling pathways such as JAK/STAT as well as pathways previously unreported in ALK-positive ALCL including mitogen-activated protein kinase (MAPK), WNT, nuclear factor kappa B (NF- $\mathrm{KB})$, transforming growth factor $\beta$ (TGF $\beta$ ), peroxisome proliferator-activated receptor (PPAR), and integrin signaling. Our studies demonstrate some of the molecular mechanisms by which Hsp90 inhibition leads to reduced viability of ALK-positive ALCL cells and reveals cellular proteins whose expression is changed due to GA inhibition of Hsp90.

\section{Materials and methods}

\subsection{Cell culture}

The ALK-positive ALCL suspension cell line, SU-DHL-1, was obtained from the German Collection of Microorganisms and Cell Cultures (DSMZ, Braunschweig, Germany). Cells were cultured in RPMI 1640 (Life Technologies, Grand Island, NY) supplemented with 15\% heat-inactivated FBS (Nova-Tech, Grand Island, NE), 25 mM HEPES (Invitrogen, Carlsbad, CA), 2 mM GlutaMAX ${ }^{\text {TM }}$ (Invitrogen), and 1\% antibiotic/antimycotic solution (Invitrogen) at $37^{\circ} \mathrm{C}$ in a humidified atmosphere of $95 \%$ oxygen and $5 \% \mathrm{CO}_{2}$.

\subsection{Cell proliferation assay}

Cells were seeded in 6-well plates at a density of $5 \times 10^{5}$ cells/ $\mathrm{mL}$ in a final volume of $2 \mathrm{~mL}$ and subsequently treated with DMSO (vehicle) or concentrations of GA (A.G. Scientific, San Diego, CA) ranging from $0.032 \mu \mathrm{M}$ through $100 \mu \mathrm{M}$ in a volume of $10 \mu \mathrm{L}$. For each GA concentration, cultures were maintained in triplicate. At the end of 6-, 12-, and 24-h, $1 \times 10^{4}$ cells from each control and GA dose were seeded in 96-well plates in triplicate and exposed to $10 \mu \mathrm{L}$ of WST-1 labeling solution (WST-1 cell proliferation reagent; Roche Diagnostics, Indianapolis, IN) and subsequently returned to the incubator for a period of $2 \mathrm{~h}$. The rate of WST- 1 cleavage by mitochondrial dehydrogenases was measured by absorbance at $450 \mathrm{~nm}$ using an ELISA plate reader (Molecular Devices, Sunnyvale, CA), with a reference wavelength of $600 \mathrm{~nm}$.

\subsection{Cell cycle analysis of DNA content}

Cells $\left(2 \mathrm{~mL} ; 5 \times 10^{5}\right.$ cells $/ \mathrm{mL}$ in 6 -well plates) were treated with $10 \mu \mathrm{M}$ GA for $24 \mathrm{~h}$, harvested after 6,12 , and $24 \mathrm{~h}$, and prepared for cell cycle analysis as described [23]. Briefly, $1 \times 10^{5}$ control and GA-treated cells were fixed in $70 \%$ ethanol and stained with $0.1 \%$ sodium citrate, $200 \mu \mathrm{g} / \mathrm{mL} \mathrm{RNa}$ seA, $0.5 \% \mathrm{NP}-40$ and $1 \mathrm{mg} / \mathrm{mL}$ propidium iodide (PI) and analyzed using an Epics XL-MCL flow cytometer (Beckman Coulter, Fullerton, CA). Cell cycle phase distribution was determined using EXPO32 ${ }^{\text {TM }}$ software (Beckman Coulter). Three independent experiments were performed in triplicate.

\subsection{Analysis of apoptosis}

Cells $\left(2 \mathrm{~mL} ; 5 \times 10^{5}\right.$ cells $/ \mathrm{mL}$ in 6 -well plates) were treated with $10 \mu \mathrm{M}$ GA for $24 \mathrm{~h}$, harvested after 6,12 , and $24 \mathrm{~h}$, and prepared for flow cytometric analysis as described [24]. 
Briefly, $1 \times 10^{6}$ control and GA-treated cells were stained with $10 \mu \mathrm{L}$ annexin V-FITC (Miltenyi Biotechnology, Auburn, CA) and $10 \mu \mathrm{L}$ PI (Miltenyi Biotechnology) and analyzed on an Epics XL-MCL flow cytometer. Three independent experiments were performed in triplicate.

\subsection{Caspase-3 activity assay}

Cells $\left(2 \mathrm{~mL} ; 5 \times 10^{5}\right.$ cells $/ \mathrm{mL}$ in 6 -well plates) were treated with $10 \mu \mathrm{M}$ GA for $24 \mathrm{~h}$. Caspase-3 protease activity was assessed using the colorimetric Caspase-Glo ${ }^{\mathrm{TM}} 3 / 7$ colorimetric assay (Promega, Madison, WI) following the manufacturer's protocol. Briefly, $1 \times 10^{4}$ cells were harvested after 6,12 , and $24 \mathrm{~h}$, seeded in 96-well white-walled plates, and incubated with $100 \mu \mathrm{L}$ of caspase- 3 substrate, Ac-DEVDaminoluciferin. After ambient incubation in the dark for $1 \mathrm{~h}$, the release of aminoluciferin was measured on a luminometer (ThermoLabsystems, Waltham, MA). Readings for blank control was subtracted from experimental readings. Furthermore, cells were treated with $100 \mu \mathrm{M}$ caspase- 3 inhibitor, Z-DEVD-FMK (EMD Biosciences, San Diego) for 15 min followed by $10 \mu \mathrm{M}$ GA and assay repeated. Three independent experiments were performed in triplicate.

\subsection{Protein isolation and immunoprecipitation}

Briefly, cells were collected by centrifugation and washed twice in PBS. Whole cell lysates were prepared using $500 \mu \mathrm{L}$ RIPA lysis buffer (1\% NP-40, 0.1\% SDS, 0.5\% DOC, 20 mM Tris (pH 7.5), $100 \mathrm{mM} \mathrm{NaCl}, 0.2 \%$ protease inhibitor, and $2 \mathrm{mM}$ activated sodium orthovanadate). After 30-min incubation on ice, samples were centrifuged at $14000 \mathrm{rpm}$ for $15 \mathrm{~min}$ at $4^{\circ} \mathrm{C}$. Supernatants were recovered and protein concentrations determined using the Bradford colorimetric assay with BSA standards (Pierce Chemical, Rockford, IL).

\subsection{Immunoblot analysis}

For immunoblot analysis, $25 \mu \mathrm{g}$ of lysate from control and GA-treated cells were mixed with $10 \mu \mathrm{L}$ of Laemmli reducing buffer and heated at $95^{\circ} \mathrm{C}$ for $5 \mathrm{~min}$. Samples were subsequently resolved by SDS-PAGE on 4-12\% gel and electrophoretically transferred to PVDF membranes. Membranes were blocked for $1 \mathrm{~h}$ in blocking solution (5\% nonfat milk diluted in TBS (20 mM Tris-HCl, pH 7.4, $150 \mathrm{mM} \mathrm{NaCl}$, and $0.1 \%$ Tween-20)). The following antibodies were used for immunoblot analysis: mouse polyclonal antibodies against PARP, p21, and p27; goat polyclonal antibodies against ras GTPase-activating protein 3 (RARS3), paracellin-1 (PCLN1), and stanniocalcin-1 (STCN1); and rabbit polyclonal antibody against actin from Santa Cruz Biotechnology (Santa Cruz, CA); mouse polyclonal antibodies against Hsp90 and NEMO (Becton Dickinson Pharmingen, San Diego); rabbit polyclonal antibodies against phospho-ALK and ALK (Cell Signaling, Beverly, MA); rabbit polyclonal antibody against ubiquitin-specific protease 9 (USP9) (Abgent, San Diego); mouse polyclonal antibodies against tankyrase (TNKS) and osteoprotegerin (OPG) and rabbit polyclonal antibodies against suppressor of cytokine signaling 4 (SOCS4; Acris Antibodies, Hiddenhausen, Germany). Membranes were incubated from $1 \mathrm{~h}$ at room temperature to $4^{\circ} \mathrm{C}$ overnight with primary antibodies in TBST containing $3 \%$ nonfat dry milk, washed five times with TBST, and probed with HRPlabeled secondary antibody at room temperature for $1 \mathrm{~h}$. After five washes with TBST, immunoreactive bands were visualized by chemiluminescence (Amersham Biosciences, Piscataway, NJ). Densitometry was performed using Image J software (National Institutes of Health (NIH), Bethesda, $\mathrm{MD}$ ) and values were normalized to actin controls.

\section{8 cICAT labeling of proteins and 3-D LC-MS/MS}

SU-DHL-1 control and cells exposed to $10 \mu \mathrm{M}$ GA were harvested after $12 \mathrm{~h}$ incubation and prepared for analysis of differential protein expression as described in ref. [25] (see Fig. 1 for illustration). Briefly, $400 \mu \mathrm{g}$ of protein from both samples were reduced with $2.5 \mathrm{mM}$ Tris (2-carboxyethyl) phosphine (Sigma) for 1 -h at $37^{\circ} \mathrm{C}$. Isotope labeling was performed by mixing $1 \mathrm{U}$ of light (control sample) or heavy (GA-treated sample) cleavable cICAT reagent with protein samples, following manufacturer's protocol (Applied Biosystems). Labeled proteins from control and treated samples were mixed and dialyzed against $500 \mathrm{~mL}$ of urea buffer $(2 \mathrm{M}$ urea, $10 \mathrm{mM}$ Tris, $\mathrm{pH}$ 8.5) three times for 1 -h each at room temperature using a $3.5 \mathrm{kDa}$ cutoff dialysis cassette (Pierce). The dialyzed protein mixtures were then diluted two-fold with $10 \mathrm{mM}$ Tris, $\mathrm{pH} 8.5$, before digestion with $10 \mu \mathrm{g}$ of modified trypsin (Promega) overnight at $37^{\circ} \mathrm{C}$. The peptide mixture was then acidified to $\mathrm{pH} \leq 3.0$ by adding TFA before loading onto the cation exchange column. The 3-D liquid chromatographic separation of peptides was performed by first, strong cation-exchange (SCX) chromatography using a $3.6 \mathrm{~mm} \times$ $20 \mathrm{~cm}$ polysulfoethyl A column (Poly LC, Columbia, MD) at a flow rate of $400 \mu \mathrm{L} / \mathrm{min}$ with 35 fractions collected (800 $\mu \mathrm{L} /$ fraction). A two-step linear buffer gradient was used: $5 \%$ buffer B and $95 \%$ buffer A to $25 \%$ buffer B and $75 \%$ buffer A for 50 min followed by $25 \%$ buffer B and $75 \%$ buffer

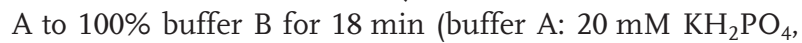
25\% ACN pH 3.0; buffer B 350 mM KCL in buffer A pH 3.0). Next, 35 fractions collected from the offline SCX chromatography were further washed and purified by avidin affinity chromatography (Applied Biosystems) to enrich for cysteine containing (cICAT-labeled) peptides followed by drying and cleaving of eluted peptides. Finally, a $15 \mu \mathrm{L}$ aliquot of each sample was analyzed by automated nanoflow RP LC/MS using the LCQ Deca XP IT mass spectrometer (ThermoFinnigan, San Jose, CA). Digested peptides were injected by an autosampler, using an ACN gradient $(0-60 \% \mathrm{~B}$ in $120 \mathrm{~min} ; A=5 \% \mathrm{ACN}$ with $0.4 \%$ acetic acid and $0.005 \%$ HFBA) through a RP column $(75 \mu \mathrm{m}$ id fused silica packed in-house with $10 \mathrm{~cm}$ of $5 \mu \mathrm{m} \mathrm{C18}$ particles) to elute the peptides at a flow rate of $\sim 200 \mathrm{~nL} / \mathrm{min}$ into the mass spectrom- 


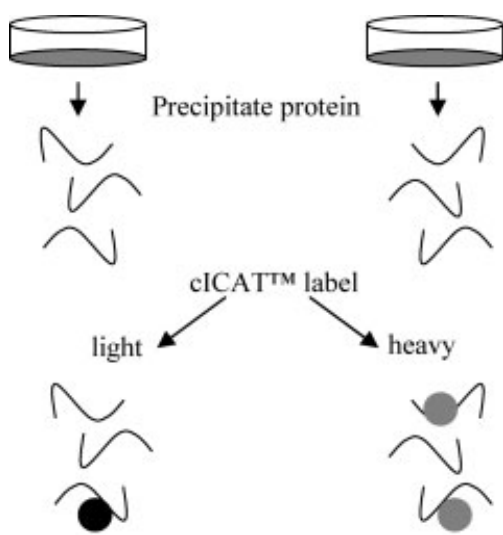

Mix \& proteolyze

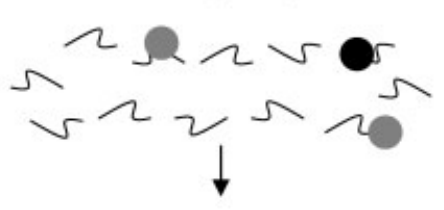

Avidin affinity chromatography

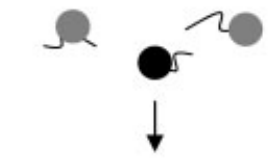

Analyze by RP-LC-MS/MS

Figure 1. cICAT strategy to isolate and identify differentially expressed proteins in GA-treated cells relative to control. Cells were in the presence of $1 \%$ DMSO (control) or $10 \mu \mathrm{M} \mathrm{GA}$ for $12 \mathrm{~h}$. Total cellular protein was precipitated under reduced conditions. Total protein from control cells was labeled with the light cICAT reagent (black circle) and protein from GA-treated cells labeled with the heavy cICAT reagent (gray circles). Samples were mixed, proteolyzed in trypsin, and subjected to avidin affinity chromatography. Isolated cICAT-labeled peptides were subjected to LCMS/MS to quantitate and identify differentially expressed proteins.

eter. An electrospray voltage of $1.8 \mathrm{kV}$ was used with the ion transfer tube temperature set to $200^{\circ} \mathrm{C}$. Peptide analysis was performed using data-dependent acquisition of one MS scan (600-2000 m/z) followed by MS/MS scans of cICAT peptide pairs triggered by the isotope tag mass difference of $9.0 \mathrm{amu}$. To obtain better peptide coverage, dynamic exclusion was set to a repeat count of 3 , with the exclusion duration of $5 \mathrm{~min}$.

\subsection{Data analyses}

The MS/MS acquired data were searched using the SEQUEST algorithm in Bioworks 3.1 (ThermoFinnigan) against human amino acid sequences in the 9.23.2004 download of the NCBI nr.fasta protein database with 191136 entries. Protein search parameters included a precursor peptide mass tolerance of $\pm 0.7 \mathrm{amu}$ and fragment mass tolerance of $\pm 0.1 \mathrm{amu}$. To account for the isotope label, sta- tic modification of cysteine was set to 227.13 and differential modification of cysteine set as 9.0. The search was constrained to tryptic peptides with one missed enzyme cleavage allowed. The peptide matching criteria of a cross correlation score $\left(X_{\text {corr }}\right)>1.2$ for +1 peptides, $>2.2$ for +2 peptides, and $>3.2$ for +3 peptides, and a delta correlation score $\left(\Delta C_{n}\right)>0.100$ was used as a threshold of acceptance. cICAT protein quantification was performed using XPRESS ${ }^{\mathrm{TM}}$ software (Thermo) which automatically calculates the relative abundance of light and heavy cICAT-labeled peptide as a ratio of light database containing both forward and reverse amino acid sequences for each protein entry. The total number of proteins identified with reverse sequence entries is then multiplied $(2 \times)$ to compensate for doubling the size of the database. Overall, the predicted false positive rate for protein identification by LC-MS/MS was 7.1\%.

Differentially expressed proteins were further analyzed using the Ingenuity ${ }^{\mathrm{TM}}$ Pathways Analysis (Ingenuity, Mountain View, CA) web-based application software tool and Bioinformatics Harvester database. Protein accession numbers and corresponding cICAT expression values were saved into the Ingenuity Systems template.xls file. Files were submitted on-line for analysis and comparison to the Ingenuity gene/protein interaction knowledge base (http://www. ingenuity.com/). The results for the pathways and protein interactions were summarized and interaction network images generated with respect to putative canonical pathways. Individual proteins were submitted to the Bioinformatics Harvester database (http://harvester.embl.de/) and protein functional characteristics analyzed.

\section{Results}

\subsection{GA reduces cell viability}

In order to establish the proteome-wide changes induced by GA in ALK-positive ALCL cells, we first sought to assess the effects of GA on cell viability.

Previous studies have demonstrated that ansamycins target Hsp90 and inhibit its function as a molecular chaperone. To determine if GA induced similar effects on ALK-positive ALCL cells, we cultured the NPM-ALK-positive ALCL cell line, SU-DHL-1, with increasing concentrations of GA up to $24 \mathrm{~h}$ and measured cell viability using the WST-1 assay. As shown in Fig. 2A, the most effective drug concentration was between 4 and $20 \mu \mathrm{M}$, with $\mathrm{IC}_{50}$ values of $10.9,13.3$, and $13.6 \mu \mathrm{M}$ at 6 , 12 , and $24 \mathrm{~h}$, respectively. There was no statistically significant reduction in viability between 20 and $100 \mu \mathrm{M}$ demonstrating the maximum effects of the drug. We subsequently treated SU-DHL-1, Karpas299, and DEL cells in the presence or absence of $10 \mu \mathrm{M}$ GA and measured cell viability at 6,12 , and $24 \mathrm{~h}$. Figure 2B illustrates the effects of GA on cell viability in a time-dependent manner. Based on our preliminary dose-dependence results, we selected a concentration of $10 \mu \mathrm{M}$ for subsequent experiments. 
A.

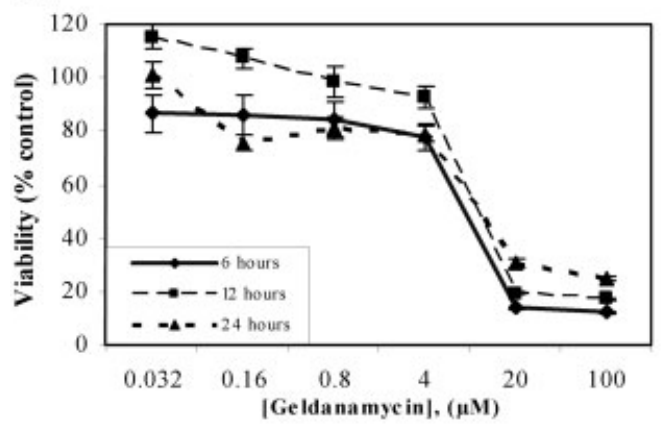

C.
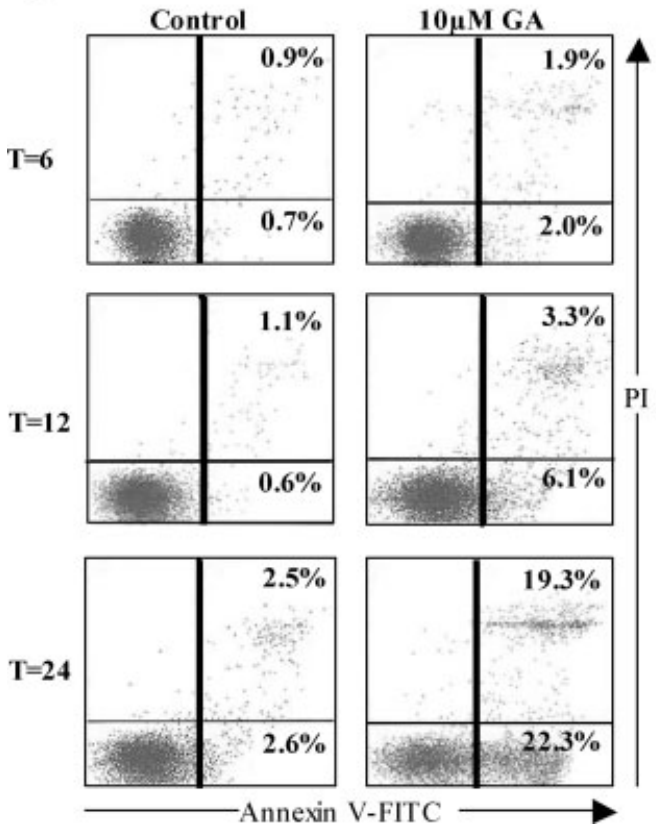

B.

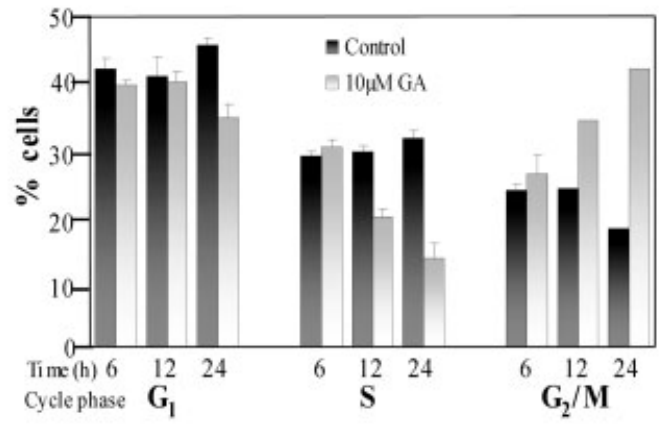

D.

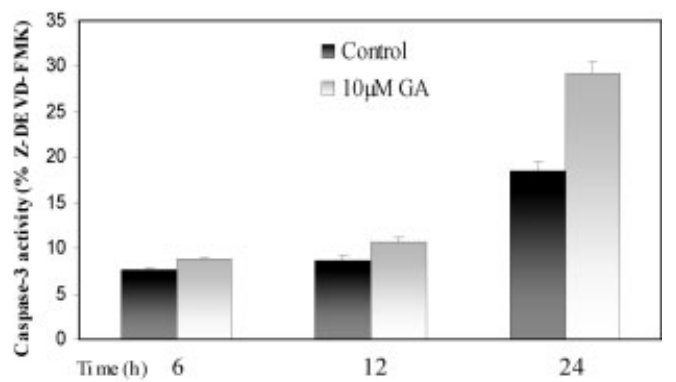

Figure 2. (A) GA reduces cell viability. Cells were cultured in the presence of $1 \%$ DMSO or various concentrations of GA for the indicated times and cell viability assessed by WST-1 reduction assay. Concentrations of GA are listed on the $x$-axis. Viability as percent of control is listed on the $y$-axis. Results are expressed as the mean of three independent experiments performed in triplicate \pm SDs. Data are normalized to DMSO control. (B) GA induces $\mathrm{G}_{2} / \mathrm{M}$ cell cycle arrest. Control and GA-treated cells were harvested and fixed after 6 , 12, and $24 \mathrm{~h}$ incubation. Cellular DNA content was determined by flow cytometric analysis after RNase treatment and PI staining. Time and DNA content are denoted on the $x$-axis and \% cells are denoted on the $y$-axis. Results are expressed as the mean of three independent experiments, performed in triplicate \pm SDs. (C) GA induces apoptosis. Control and GA-treated cells were harvested after 6, 12, and $24 \mathrm{~h}$ and stained with annexin V-FITC/PI. Cellular apoptosis was determined by flow cytometric analysis. Annexin V-FITC staining is denoted on the $x$-axis. PI staining is denoted on the $y$-axis. Left panels illustrate the staining patterns of control for each time point. Right panels illustrate the staining patterns of GA-treated cells for the same time points. The percent of cells in each particular quadrant represents the mean of three independent experiments. SDs were within $5 \%$ of the mean. (D) GA-induced apoptosis is mediated by caspase-3. Control and GA-treated cells were harvested after 6,12 , and $24 \mathrm{~h}$. Caspase- 3 activity was determined by luminescence detection of caspase- 3 substrate cleavage. Time is denoted on the $x$-axis. The increase in caspase-3 luminescence as a percent of Z-DEVD-FMK control is denoted on the $y$-axis. Results are expressed as the mean values of three independent experiments, performed in triplicate \pm SDs.

\subsection{GA induces $G_{2} / M$ cell cycle arrest}

We investigated the effects of GA on cell cycle phase distribution to determine whether cell viability reduction was caused by disruption of cell cycle-related events. Cells cultured in $10 \mu \mathrm{M}$ GA were harvested at the indicated times, stained with PI, and subjected to cell cycle analysis. The percent of cells in $G_{1}$ were unchanged at 6 and $12 \mathrm{~h}$, but were reduced by $10.8 \%$ after $24 \mathrm{~h}$, relative to control (Fig. 2C). A reduction of cells in S-phase was seen at 12 and $24 \mathrm{~h}$ by 9.9 and $18 \%$, respectively, compared to control. In contrast, cells in $\mathrm{G}_{2} / \mathrm{M}$ increased by 10.4 and $24.2 \%$ after 12 
and $24 \mathrm{~h}$, compared to control. These data suggest that the reduction of cell viability is due to a block in the $G_{2} / M$ transition.

\subsection{GA induces caspase-3-mediated apoptosis}

To further analyze the effects of GA on cell viability, we performed time-course flow cytometric analysis of annexin $\mathrm{V}$ FITC/PI stained cells. Figure 2D illustrates the time-dependent increase in apoptotic cells in response to GA after 6, 12 , and $24 \mathrm{~h}$. The fraction of early and late apoptotic cells (annexin V-positive/PI negative and annexin V-positive/PIpositive) increased by $2.3 \%$ at $6 \mathrm{~h}, 7.7 \%$ at $12 \mathrm{~h}$, and $36.5 \%$ at $24 \mathrm{~h}$, respectively, relative to control. To evaluate the mechanism of GA-induced apoptosis, we analyzed caspase- 3 activity. As shown in Fig. 2E, GA induced a time-dependent increase in caspase- 3 activity by $1.3,2.0$, and $10.7 \%$ at 6,12 , and $24 \mathrm{~h}$, respectively, relative to control. Furthermore, caspase- 3 activity was completely inhibited by the caspase- 3 inhibitor Z-DEVD-FMK at all time points. These results demonstrate that GA induces caspase-3-mediated apoptosis.

\subsection{Effects of GA on NPM-ALK, Hsp90, cell cycle regulatory proteins, and apoptosis regulatory proteins}

To examine the underlying mechanisms by which GA arrested cells in $\mathrm{G}_{2} / \mathrm{M}$ and induced caspase-3-mediated apoptosis, we performed immunoblot analysis to determine relative expression of phosphorylated and nonphosphorylated NPMALK, Hsp90, p21 ${ }^{\mathrm{CIP} 1}, \mathrm{p} 27^{\mathrm{KIP} 1}$, and PARP. After $12 \mathrm{~h}$ drug treatment, the expression of both nonphosphorylated and phosphorylated NPM-ALK expression was markedly reduced in GA-treated cells (Fig. 3). In contrast, expression of Hsp90 remained unchanged. While expression of the Cdk2 inhibitor, p $21^{\mathrm{CIP} 1}$ was unchanged, the expression of the Cdk4 inhibitor, p $27^{\mathrm{KIP} 1}$ was induced in GA-treated cells. Moreover, PARP underwent cleavage into its $85 \mathrm{kDa}$ fragment with GA treatment, consistent with apoptosis. The levels of actin remained unchanged.

\subsection{MS/MS analysis of cICAT-labeled peptides}

We sought to survey the proteomic changes induced by GA inhibition of Hsp90 using cICAT- LC-MS/MS. Top protein database search hits from SEQUEST were summarized using BioWorks 3.1 and the relative quantification calculated using XPRESS. Figure 4 displays an example of the MS-full scan and MS/MS scan for the cICAT-labeled peptide sequence corresponding to SOCS4. Examination of the data from 35 individual SCX fractions resulted in a total of 2921 peptides identified, which were matched to 1129 known NCBI database entries and 314 unique proteins. Of the 176 cICAT-labeled peptides, 119 were differentially expressed by 1.5 -fold or greater at $12 \mathrm{~h}$. Over- and underexpressed proteins

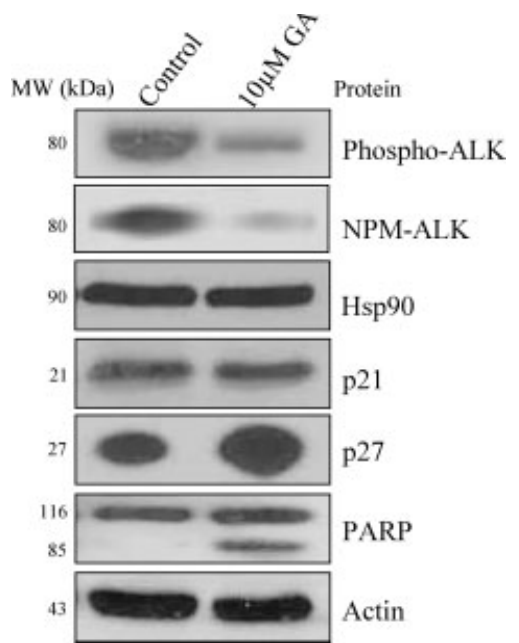

Figure 3. GA inhibition of Hsp90 influences expression of a variety of proteins. Total cell lysate was extracted from control and GAtreated cells after $12 \mathrm{~h}$ and proteins separated by SDS-PAGE. Immunoblots were probed with antiphospho-ALK (1:1000), antiNPM-ALK (1:1000), anti-Hsp90 (1:1500), anti-p21 (1:500), anti-p27 (1:500), anti-PARP (1:1500), and antiactin (1:500); incubated at room temperature for $1 \mathrm{~h}$ (Hsp90, p21, p27, PARP, and actin) or overnight at $4{ }^{\circ} \mathrm{C}$ (phospho-ALK and NPM-ALK), followed by probing with respective horseradish-peroxidase conjugated secondary antibodies and visualized by chemiluminescence. Actin served as a loading control. Protein sizes are listed left of each immunoblot.

were categorized by biological process (Table 1). A large number of the differentially expressed proteins were downregulated (59\%) in response to GA.

The Bioinformatics Harvester database (http://harvester. embl.de/) was used to perform analysis of protein functional characteristics using the 1.5 -fold threshold. Seventy-seven percent of the proteins identified and quantified have known functions, while $23 \%$ were assigned to the hypothetical category. Furthermore, $84 \%$ of the identified proteins were assigned to nuclear, cytoplasmic, membranous, or extracellular locations while the subcellular locations of the remaining $16 \%$ are unknown. Figure 5A illustrates localization of overexpressed proteins and Fig. 5B illustrates localization of underexpressed proteins in GA-treated cells. Analysis of localization demonstrated the majority of proteins exist in the nucleus and cytoplasm (67\% of overexpressed and $75 \%$ of underexpressed).

Analysis of biological pathways of differentially expressed proteins using the Ingenuity Pathways Analysis tool revealed deregulated proteins involved in a variety of pathways, including integrin, estrogen receptor, MAPK, JAK/ STAT, PPAR, and NF-кB signaling as well as those involved in ubiquitin-mediated proteolysis and cell cycle regulation. Several of the proteins are involved in multiple functions such as the versus heavy [25].

The false-positive error rate for protein identifications was calculated using the composite target/decoy database method [26]. Acquired MS/MS spectra were searched against 
Table 1. Differentially expressed proteins of 1.5-fold over- and underexpressed, categorized by biological function

\begin{tabular}{|c|c|c|c|c|c|c|c|}
\hline & Name & Description & $\mathrm{NCBI}$ & Fold & Peptides & $X_{\text {corr }}$ & $\begin{array}{l}\text { Charge } \\
\text { state }\end{array}$ \\
\hline \multicolumn{8}{|l|}{ Cell signaling } \\
\hline \multirow[t]{11}{*}{ Overexpressed } & MAP4K1 & $\begin{array}{l}\text { Mitogen-activated protein kinase } \\
\text { kinase kinase kinase } 1\end{array}$ & 6005810 & 25.0 & -.SSSLGIPDADC*CR.- & 1.38 & 1 \\
\hline & WNT10B & $\begin{array}{l}\text { Wingless-type MMTV integration } \\
\text { site family, member 10B } \\
\text { precursor }\end{array}$ & 16936522 & 8.3 & -.C*HGTSGSCOFK.- & 2.58 & 2 \\
\hline & CLK2 & $\begin{array}{l}\text { Dual specificity protein kinase } \\
\text { CLK2 (CDC-like kinase 2) }\end{array}$ & 1705919 & 3.6 & -.VVOC*VDHRRGGAR.- & 2.62 & 2 \\
\hline & RASA3 & $\begin{array}{l}\text { Ras GTPase-activating protein } 3 \\
\text { (GAP1(IP4BP)) }\end{array}$ & 13959562 & 2.8 & -.ALYIQANNC*VEAK.- & 2.53 & 2 \\
\hline & PLEKHA2 & $\begin{array}{l}\text { Pleckstrin homology domain- } \\
\text { containing protein family A } \\
\text { member } 2\end{array}$ & 48474645 & 2.4 & -.TPFC*FVINALSQR.- & 2.54 & 2 \\
\hline & RAPGEF6 & $\begin{array}{l}\text { Rap guanine nucleotide } \\
\text { exchange factor } 6\end{array}$ & 34395686 & 2.3 & -.LLNIAC*AAKAKWR.- & 2.52 & 2 \\
\hline & MAPK14 & $\begin{array}{l}\text { Mitogen-activated protein } \\
\text { kinase kinase kinase } 14\end{array}$ & 4505397 & 2.2 & -.LISPLQC*LNHVWK.- & 1.23 & 1 \\
\hline & STC1 & Stanniocalcin 1 & 4507265 & 2.1 & -.ESLKC*IANGVTSK.- & 2.12 & 1 \\
\hline & IL1R1 & $\begin{array}{l}\text { Interleukin-1 receptor, type I } \\
\text { precursor }\end{array}$ & 4504659 & 1.9 &.$- Q C *$ GYKLFIYGR.- & 2.05 & 1 \\
\hline & ARHGAP20 & $\begin{array}{l}\text { Rho GTPase-activating } \\
\text { protein } 20\end{array}$ & 25535895 & 1.8 & -.VSLLIQFLIENC*LR.- & 1.48 & 1 \\
\hline & SMAD5 & $\begin{array}{l}\text { SMAD, mothers against DPP } \\
\text { homolog 5; Dwfc }\end{array}$ & 47778925 & 1.8 & -.PLDIC*EFPFGSK.- & 2.65 & 2 \\
\hline \multirow[t]{13}{*}{ Underexpressed } & GRIN2D & $\begin{array}{l}N \text {-methyl-D-aspartate receptor } \\
\text { subunit 2-D precursor; } \\
\text { estrogen receptor }\end{array}$ & 4504131 & 7.1 & -.CC*KGFC*IDILKR.- & 3.00 & 2 \\
\hline & IL26 & Interleukin 26 precursor & 8923756 & 7.1 & -.C*GLLLVTLSLAIAK.- & 2.59 & 2 \\
\hline & ZP4 & $\begin{array}{l}\text { Zona pellucida glycoprotein } 4 \\
\text { preproprotein; zona } \\
\text { pellucida B protein }\end{array}$ & 10863987 & 7.1 & $-. K L L K C * P M D L L A R .-$ & 2.55 & 2 \\
\hline & PTK2B & $\begin{array}{l}\text { Protein tyrosine kinase } 2 \beta \\
\text { isoform a; (PTK2B) cell } \\
\text { adhesion kinase }\end{array}$ & 27886584 & 6.7 & -.PTC*LAEFKQIRSIR.- & 1.45 & 1 \\
\hline & PI-G PLD & $\begin{array}{l}\text { Similar to phosphatidylinositol- } \\
\text { glycan-specific }\end{array}$ & 28828281 & 5.6 & -.C*NAILYAGAMGVK.- & 1.60 & 1 \\
\hline & STIP $1 * *$ & $\begin{array}{l}\text { Stress-induced-phospho- } \\
\text { protein } 1 \text { (Hsp70/Hsp90- } \\
\text { organizing protein) }\end{array}$ & 5803181 & 5.0 & -.ELC*EKAIEVGRENR.- & 1.38 & 1 \\
\hline & PDC & $\begin{array}{l}\text { Phosducin isoform a; } \mathrm{G} \beta \gamma \\
\text { binding protein }\end{array}$ & 32967591 & 4.6 & -.FC*KIKASNTGAGDR.- & 2.62 & 2 \\
\hline & RAD17 & $\begin{array}{l}\text { Checkpoint protein, involved in } \\
\text { the activation of the DNA } \\
\text { damage }\end{array}$ & 6324944 & 4.0 & -.DYPGIVIEVC* MLEK.- & 2.56 & 2 \\
\hline & CBLC & $\begin{array}{l}\text { Signal transduction protein } \\
\text { CBL-C (SH3-binding protein } \\
\text { CBL-C) }\end{array}$ & 46397888 & 3.6 & -.APAHTFWRESC*GAR.- & 2.58 & 2 \\
\hline & GRB7 & $\begin{array}{l}\text { Growth factor receptor-bound } \\
\text { protein } 7\end{array}$ & 4885355 & 2.5 & -.PHVVKVYSEDGAC*R.- & 1.38 & 1 \\
\hline & RPS6KB1 & $\begin{array}{l}\text { Ribosomal protein S6 kinase, } \\
70 \mathrm{kDa} \text {, polypeptide } 1\end{array}$ & 4506737 & 2.5 & -.IRPEC*FELLRVLGK.- & 2.19 & 1 \\
\hline & SOCS4 & $\begin{array}{l}\text { Suppressor of cytokine } \\
\text { signaling } 4 \text { (SOCS4) }\end{array}$ & 20178095 & 2.4 & -.PTNSEETC*IKMEVR.- & 1.90 & 1 \\
\hline & ANAPC4 & $\begin{array}{l}\text { Anaphase promoting complex } \\
\text { subunit } 4 \text { (APC4) }\end{array}$ & 37537862 & 2.4 & -.SMNQAIC*IPLYR.- & 2.79 & 2 \\
\hline
\end{tabular}


Table 1. Continued

\begin{tabular}{|c|c|c|c|c|c|c|c|}
\hline & Name & Description & $\mathrm{NCBI}$ & Fold & Peptides & $X_{\text {corr }}$ & $\begin{array}{l}\text { Charge } \\
\text { state }\end{array}$ \\
\hline & IKBKG** & $\begin{array}{l}\text { Inhibitor of kappa light } \\
\text { polypeptide gene enhancer } \\
\text { in B-cells (NEMO) }\end{array}$ & 4504631 & 2.4 & -.C*OQQMAEDKASVK.- & 2.54 & 2 \\
\hline & T3JAM & $\begin{array}{l}\text { TRAF3-interacting JNK-activating } \\
\text { modulator }\end{array}$ & 13435127 & 2.2 & -.C*RPNVTTCROVGK.- & 1.40 & 1 \\
\hline & MAK** & Male germ cell-associated kinase & 11496279 & 2.1 & -.KFYSWDEC*MNLR.- & 2.52 & 2 \\
\hline & PDE5A & $\begin{array}{l}\text { Phosphodiesterase 5A isoform } 1 \\
\text { cGMP-binding cGMP-specific }\end{array}$ & 4505667 & 2.0 & -.VHTIPVC*KEGIR.- & 1.31 & 1 \\
\hline & RAC3 & $\begin{array}{l}\text { Ras-related C3 botulinum toxin } \\
\text { substrate } 3\end{array}$ & 4826962 & 2.0 & -.HHC*PHTPILLVGTK.- & 1.41 & 1 \\
\hline & TNFRSF11B & $\begin{array}{l}\text { Human osteoprotegerin (OPG) } \\
\text { protein }\end{array}$ & 2072185 & 1.8 & -.VGAEDIEKTIKAC*K.- & 1.57 & 1 \\
\hline & DKK2 & $\begin{array}{l}\text { Dickkopf homolog 2; Dickkopf } \\
\text { gene } 2\end{array}$ & 7657023 & 1.7 & -.GKNLGQAYPC*SSDK.- & 2.63 & 2 \\
\hline & + & $\begin{array}{l}\text { Myelin oligodendrocyte } \\
\text { glycoprotein isoform } 2\end{array}$ & 45580732 & 1.6 & -.FSDEGGFTC*FFR.- & 2.58 & 2 \\
\hline \multicolumn{8}{|l|}{ DNA metabolism } \\
\hline \multirow[t]{4}{*}{ Overexpressed } & ZNF297 & $\begin{array}{l}\text { Zinc finger protein } 297 \\
\quad \text { (BING1 protein) }\end{array}$ & 23396973 & 9.1 & -.PFDCPVC*NKKFK.- & 1.34 & 1 \\
\hline & CTCF & $\begin{array}{l}\text { CССТC-binding factor (zinc } \\
\text { finger protein) }\end{array}$ & 5729790 & 2.6 & -.PHKC*HLCGRAFR.- & 2.11 & 1 \\
\hline & OIP106 & $\begin{array}{l}106 \mathrm{kDa} \text { O-GIcNAc transferase- } \\
\text { interacting protein }\end{array}$ & 13124654 & 1.7 & -.YFLLC*AERVGQMTK.- & 1.29 & 1 \\
\hline & THOC1 & Nuclear matrix protein p84 & 4826882 & 1.7 & -.QIEC*DSEDMKMRAK.- & 2.13 & 1 \\
\hline \multirow[t]{11}{*}{ Underexpressed } & GTBP & GTBP-N protein & 7512474 & 6.7 & -.GLSFPRRGC*GLER.- & 2.80 & 2 \\
\hline & TNKS & $\begin{array}{l}\text { Tankyrase, TRF1-interacting } \\
\text { ankyrin-related ADP-ribose } \\
\text { polymerase }\end{array}$ & 4507613 & 4.2 & -.ELLEAC*RNGDVSR.- & 2.78 & 2 \\
\hline & HILS1 & $\begin{array}{l}\text { Spermatid-specific linker } \\
\text { histone H1-like protein }\end{array}$ & 34850057 & 4.0 & -.GTC*KYVSLATLKK.- & 2.52 & 2 \\
\hline & + & $\begin{array}{l}\text { Similar to cofactor required } \\
\text { for } \mathrm{Sp} 1 \text { transcriptional } \\
\text { activation }\end{array}$ & 38086032 & 3.9 & -.TDALKC*RVALSPK.- & 1.51 & 1 \\
\hline & ZNF324 & $\begin{array}{l}\text { Zinc finger protein } 324 \\
\quad(\text { Homo sapiens) }\end{array}$ & 7657693 & 3.1 & -.PFRCVDC* GKAFAK.- & 2.00 & 1 \\
\hline & SNRP70 & $\begin{array}{l}\text { U1 small nuclear ribonucleo- } \\
\text { protein } 70 \mathrm{kDa}\end{array}$ & 29568103 & 3.0 & -.HHNOPYC* GIAPYIR.- & 1.28 & 1 \\
\hline & SRrp35 & $\begin{array}{l}35 \mathrm{kDa} \text { SR repressor protein } \\
\quad \text { (SRrp35) }\end{array}$ & 47606193 & 2.8 &.- HSDSIARSPC*KSPK.- & 2.50 & 2 \\
\hline & ZNF516 & Zinc finger protein 516 & 14548318 & 2.7 & -.GSFDHGC*HICGRR.- & 1.43 & 1 \\
\hline & SIX5 & Homeobox protein SIX5 & 46396941 & 2.5 & -.AC*YRGNRYPTPDEK.- & 1.85 & 1 \\
\hline & JRK & Jerky protein homolog & 27805484 & 2.1 & -.OPC*FSAQEVGQLR.- & 2.57 & 2 \\
\hline & POLRD3 & $\begin{array}{l}\text { RNA polymerase III } 53 \mathrm{kDa} \\
\text { subunit RPC4 }\end{array}$ & 4502437 & 1.9 & -.LVC*SPDFESLLDHK.- & 1.68 & 1 \\
\hline \multicolumn{8}{|c|}{ Protein metabolism } \\
\hline \multirow[t]{5}{*}{ Overexpressed } & PSMD9 & $\begin{array}{l}\text { 26S proteasome non-ATPase } \\
\text { regulatory subunit } 9\end{array}$ & 12230943 & 5.6 & -.GLLGC*NIIPLQR.- & 2.65 & 2 \\
\hline & USP9X & Ubiquitin specific protease 9 & 11641423 & 5.6 & -.WYKFDDGDVTEC*K.- & 1.56 & 1 \\
\hline & ADAMTS12 & $\begin{array}{l}\text { A disintegrin-like and metall- } \\
\text { oprotease }\end{array}$ & 13569928 & 4.4 & -.ATFC*DPETQPNGR.- & 2.55 & 5 \\
\hline & AARS & Alanyl-tRNA synthetase & 4501841 & 3.7 & -.AVYTQDC*PLAAAK.- & 2.01 & 1 \\
\hline & PSMD7 & $\begin{array}{l}\text { 26S proteasome regulatory } \\
\text { chain, p } 40\end{array}$ & 1085272 & 2.1 & -.YC*PNSVLVIIDVK.- & 2.59 & 5 \\
\hline
\end{tabular}


Table 1. Continued

\begin{tabular}{|c|c|c|c|c|c|c|c|}
\hline & Name & Description & $\mathrm{NCBI}$ & Fold & Peptides & $X_{\text {corr }}$ & $\begin{array}{l}\text { Charge } \\
\text { state }\end{array}$ \\
\hline \multirow[t]{6}{*}{ Underexpressed } & MRPS15 & $\begin{array}{l}\text { Mitochondrial ribosomal protein } \\
\text { S15; } 28 \mathrm{~S} \text { ribosomal protein } \mathrm{S} 15\end{array}$ & 16554611 & 2.7 & -.KALC*IRVFQETQK.- & 1.69 & 1 \\
\hline & PSMD2 & $\begin{array}{l}\text { Proteasome } \beta 2 \text { subunit; } \\
\text { proteasome subunit, } \\
\text { beta-type, } 2\end{array}$ & 4506195 & 2.7 & -.AVELLRKC*LEELOK.- & 1.80 & 1 \\
\hline & CAPN5 & Calpain 5 & 37577157 & 2.2 & -.NEFWC*ALVEKAYAK.- & 2.07 & 1 \\
\hline & SACS & Sacsin & 13124523 & 2.0 & -.VCQFGALC*SLQGR.- & 1.62 & 1 \\
\hline & PRSS15 & $\begin{array}{l}\text { Endopeptidase La homolog } \\
\text { (EC 3.4.21.-) precursor }\end{array}$ & 1362755 & 2.0 & -.AGVTC*IVLPAENKK.- & 2.55 & 2 \\
\hline & VCIP135 & Valosin-containing protein (p97) & 36029914 & 1.8 & -.PICC*AWSSSGR.- & 2.54 & 2 \\
\hline \multicolumn{8}{|l|}{ Cell growth } \\
\hline \multirow[t]{6}{*}{ Overexpressed } & PCLN1 & Claudin 16; paracellin-1 & 5729970 & 2.6 & -.RPVFSHC*QVPETQK.- & 1.35 & 1 \\
\hline & DRP2 & Dystrophin-related protein 2 & 4503393 & 2.6 & -.HFVPSAGADSETHC*.- & 2.66 & 2 \\
\hline & AKAP6 & A-kinase anchor protein 6 & 13431309 & 1.8 & -.TLTC*EENLLNLHEK.- & 1.85 & 1 \\
\hline & SYNE2 & $\begin{array}{l}\text { Nesprin } 2 \text { (Nuclear envelope } \\
\text { spectrin repeat protein 2) }\end{array}$ & 29839588 & 1.7 & -.PVVYDVC*DDQEIQK.- & 1.21 & 1 \\
\hline & CRYBA4 & Crystallin, beta A4 & 4503059 & 1.7 & -.MTLQC*TKSAGPWK.- & 1.38 & 1 \\
\hline & LZTS1 & $\begin{array}{l}\text { Leucine zipper, putative tumor } \\
\text { suppressor } 1\end{array}$ & 10440566 & 1.5 & -.GLELEVC*ENELORK.- & 1.87 & 1 \\
\hline \multirow[t]{5}{*}{ Underexpressed } & $\mathrm{MCPH} 1 * *$ & Estrogen receptor beta & 7441774 & 5.3 & -.CYEVGMVKC*GSR.- & 1.66 & 1 \\
\hline & XRCC4 & $\begin{array}{l}\text { X-ray repair cross comple- } \\
\text { menting protein } 4 \text { isoform } 2\end{array}$ & 12408647 & 2.0 & -.C*VSAKEALETDLYK.- & 2.12 & 1 \\
\hline & MAP1A & $\begin{array}{l}\text { Microtubule-associated protein } \\
1 \mathrm{~A} \text { (proliferation-related) }\end{array}$ & 19861596 & 1.6 & -.PCC*YIFPGGR.- & 2.06 & 1 \\
\hline & DNAH9 & Ciliary dynein heavy chain 9 & 12643822 & 1.5 & -.LNWPHMIC*EDVRR.- & 1.96 & 1 \\
\hline & TFF2 & $\begin{array}{l}\text { Trefoil factor } 2 \text { precursor; } \\
\text { spasmolytic protein 1; } \\
\text { spasmolysin }\end{array}$ & 4885629 & 1.5 & -.QESDQC*VMEVSDRR.- & 3.12 & 2 \\
\hline \multicolumn{8}{|l|}{ Metabolism } \\
\hline \multirow[t]{6}{*}{ Overexpressed } & AKAT1 & $\begin{array}{l}\text { Acetyl-Coenzyme A acetyltrans- } \\
\text { ferase } 1 \text { precursor }\end{array}$ & 4557237 & 5.3 & -.IHMGSC*AENTAKK.- & 2.68 & 2 \\
\hline & SKD3 & $\begin{array}{l}\text { Suppressor of potassium } \\
\text { transport defect } 3\end{array}$ & 13540606 & 2.9 & -.FDTKC*LAAATWGR.- & 2.70 & 2 \\
\hline & PDE6C & $\begin{array}{l}\text { Cone cGMP-specific 3',5'-cyclic } \\
\text { phosphodiesterase alpha'- } \\
\text { subunit }\end{array}$ & 1705960 & 2.6 & -.LNVDVIDDC*EEK.- & 2.50 & 2 \\
\hline & FTCD & $\begin{array}{l}\text { Formiminotransferase } \\
\text { cyclodeaminase }\end{array}$ & 11140815 & 2.3 & -.MGALDVC*PFIPVR.- & 2.53 & 1 \\
\hline & + & $\begin{array}{l}\text { Glycosylphosphatidylinositol } 1 \\
\text { homolog }\end{array}$ & 31981380 & 1.7 & -.SKLSTC*EQLHHRLK.- & 2.18 & 2 \\
\hline & $\mathrm{BCHE}$ & Butyrylcholinesterase precursor & 4557351 & 1.6 & -.LTGC*SRENETEIIK.- & 2.54 & 2 \\
\hline \multirow[t]{2}{*}{ Underexpressed } & UQCRH & $\begin{array}{l}\text { Ubiquinol-cytochrome c } \\
\text { reductase hinge protein }\end{array}$ & 5174745 & 4.6 & -.ERLELC*DERDSSR.- & 2.69 & 2 \\
\hline & ACACB & $\begin{array}{l}\text { Acetyl-CoA carboxylase (EC } \\
\quad 6.4 .1 .2)\end{array}$ & 542750 & 2.7 & -.YRITIGNKTC*VFEK.- & 1.31 & 1 \\
\hline \multicolumn{8}{|l|}{ Transport } \\
\hline \multirow[t]{3}{*}{ Overexpressed } & STX17 & Syntaxin 17 & 8923604 & 3.5 & -.LTSSC*PDLPSOTDK.- & 2.57 & 2 \\
\hline & SCN1A & $\begin{array}{l}\text { Sodium channel protein type I } \\
\text { alpha subunit }\end{array}$ & 12644229 & 3.3 & -.DSC*MSNHTAEIGK.- & 2.53 & 2 \\
\hline & CACNA1H & $\begin{array}{l}\text { Voltage-dependent T-type } \\
\text { calcium channel alpha-1H } \\
\text { subunit }\end{array}$ & 23503045 & 2.2 & -.DNGMOKC*SHIPGRR.- & 1.22 & 1 \\
\hline
\end{tabular}


Table 1. Continued

\begin{tabular}{|c|c|c|c|c|c|c|c|}
\hline & Name & Description & $\mathrm{NCBI}$ & Fold & Peptides & $X_{\text {corr }}$ & $\begin{array}{l}\text { Charge } \\
\text { state }\end{array}$ \\
\hline Underexpressed & ADFP & $\begin{array}{l}\text { Adipose differentiation-related } \\
\text { protein; adipophilin }\end{array}$ & 34577059 & 1.9 & -.LEPQIAVANTYAC*K.- & 2.77 & 2 \\
\hline \multicolumn{8}{|l|}{ Immune response } \\
\hline \multirow[t]{2}{*}{ Overexpressed } & TNFRSF6B & $\begin{array}{l}\text { Helicase-like protein NHL } \\
\text { isoform } 2\end{array}$ & 14790174 & 3.3 & -.NTSYRPKVC*VLGSR.- & 2.71 & 2 \\
\hline & HLA-B & HLA-B protein & 2118848 & 2.2 & -.MYGC*DLGPDGRFLR.- & 1.81 & 1 \\
\hline \multicolumn{8}{|l|}{ Hypothetical } \\
\hline \multirow[t]{9}{*}{ Overexpressed } & SFRS14 & KIAA0365 & 7512968 & 10.0 & -.AWLVSSGC*PLQVK.- & 2.60 & 2 \\
\hline & + & $\begin{array}{l}\text { SI:zC237L4.5 novel protein } \\
\text { similar to human procollagen }\end{array}$ & 33468666 & 7.1 & -.PHVDEHQFC*GGK.- & 2.04 & 1 \\
\hline & + & DKFZp762E1312.1 & 11283475 & 5.0 & -.C*LPKSDSSSSLPK.- & 1.87 & 1 \\
\hline & + & DKFZp434L243.1 & 7512652 & 4.4 & -.PPGGHSNLAC*ALKK.- & 2.52 & 2 \\
\hline & TRIM14 & $\begin{array}{l}\text { Tripartite motif protein TRIM14 } \\
\text { isoform alpha }\end{array}$ & 15208663 & 4.2 & & 2.51 & 2 \\
\hline & TTC4 & $\begin{array}{l}\text { Tetratricopeptide repeat } \\
\text { domain } 4\end{array}$ & 39652618 & 3.9 & -.AIIRGALC*HLELK.- & 2.63 & 2 \\
\hline & SOSTDC1 & DKFZp564D206.1 & 7512729 & 3.3 & -.SSQEWRC*VNDK.- & 2.07 & 1 \\
\hline & DLG7 & KIAA0008 & 3183208 & 3.2 & -.NVETKPDKGISC*K.- & 1.55 & 2 \\
\hline & + & KIAA0590 & 7513032 & 2.1 & -.RPLRDFVGLEDC*DK.- & 2.13 & 1 \\
\hline \multirow[t]{19}{*}{ Underexpressed } & GTF2H4 & XP_378195 & 42657571 & 20.0 & -.LYGHPATC*LAVFR.- & 2.63 & 2 \\
\hline & WDR17 & WD-repeat protein 17 & 47606182 & 4.4 & -.EGILC*SGSDDGTVR.- & 2.51 & 2 \\
\hline & + & DKFZp434M183.1 & 7512659 & 4.0 & -.DVVC*TCSLKNWR.- & 2.15 & 1 \\
\hline & FGL2 & $\begin{array}{l}\text { Fibrinogen-like 2; fibrinogen-like } \\
\text { protein 2; fibroleukin }\end{array}$ & 5730075 & 2.9 & -.DVC*PVRLESRGK.- & 2.08 & 1 \\
\hline & + & 19.0 kDa early protein & 139989 & 2.6 & -.ITKNTFSTASC*GK.- & 1.82 & 1 \\
\hline & HERPUD1 & $\begin{array}{l}\text { Homocysteine-inducible, ER } \\
\text { stress-inducible }\end{array}$ & 7661870 & 2.5 & -.AC*YRGNRYPTPDEK.- & 1.28 & 1 \\
\hline & + & $\begin{array}{l}\text { Leucine-rich repeat LGI family, } \\
\text { member } 4\end{array}$ & 21281673 & 2.3 & -.PEEELPAASVVSC*K.- & 1.60 & 1 \\
\hline & + & KIAA0232 & 30923325 & 2.3 & -.PVC*LQEIMTVWNK.- & 1.26 & 1 \\
\hline & + & $\begin{array}{l}\text { SI:zC255F14.1 (novel protein } \\
\text { similar to human RIM binding } \\
\text { protein) }\end{array}$ & 33468681 & 2.2 & -.PPC*WSSSSSROTTK.- & 1.66 & 1 \\
\hline & PGLYRP4 & $\begin{array}{c}\text { Peptidoglycan recognition } \\
\text { protein I-beta precursor }\end{array}$ & 38604973 & 1.9 & -.TSLKKAC*PGVVPR.- & 1.79 & 1 \\
\hline & + & Interleukin-14 precursor & 627504 & 1.9 & -.PARLC*LGTPFLRSR.- & 2.50 & 2 \\
\hline & ANKMY1 & $\begin{array}{l}\text { Ankyrin repeat and MYND } \\
\text { domain containing protein } 1\end{array}$ & 30912747 & 1.9 & -.ESOWDPTWLYLC*K.- & 1.95 & 1 \\
\hline & HES1 & Human HES1 protein & 5031691 & 1.9 & -.NLSTFAVDGKDC*K.- & 2.79 & 2 \\
\hline & KIAA1199 & KIAA1199 protein & 38638698 & 1.6 & -.FAFC*SMKGCERIK.- & 1.40 & 1 \\
\hline & INFA5 & Interferon alpha-G & 87983 & 1.6 & -.MC*DLPQTHSLSNRR.- & 2.14 & 1 \\
\hline & EGFL3 & $\begin{array}{l}\text { Multiple EGF-like domain } \\
\text { protein } 3\end{array}$ & 46395624 & 1.5 & -.CVC*HAGYELGADGR.- & 1.30 & 1 \\
\hline & SDF2 & $\begin{array}{l}\text { Stromal cell-derived factor } 2 \\
\text { precursor (SDF-2) }\end{array}$ & 21542241 & 1.5 & -.C*GQPIRLTHVNTGR.- & 1.84 & 1 \\
\hline & C7orf28A & DKFZp586I1023.1 & 7512900 & 1.5 & -.KLC*ATQFNNIFFLD.- & 2.01 & 1 \\
\hline & + & DKFZp434K1772.1 & 7512635 & 1.5 & -.C*PPQLRPSR.- & 2.58 & 2 \\
\hline
\end{tabular}

Cells were in the presence of $1 \%$ DMSO (control) or $10 \mu \mathrm{M} \mathrm{GA}$ for $12 \mathrm{~h}$ and total cellular protein precipitated. Samples were clCAT labeled and analyzed by LC-MS/MS. Identified peptides of 1.5-fold over- and underexpressed were searched against the Bioinformatics Harvester database for biological function. Proteins were categorized by biological function (over- or underexpressed) and listed are protein names, description, NCBI GI number, fold change, identified peptides, crosscorrelation score, and charge state.

Known Hsp90 clients or interacting proteins are designated ${ }^{*}$, cICAT labeled cysteines are designated $*$, and unnamed proteins are designated + . 

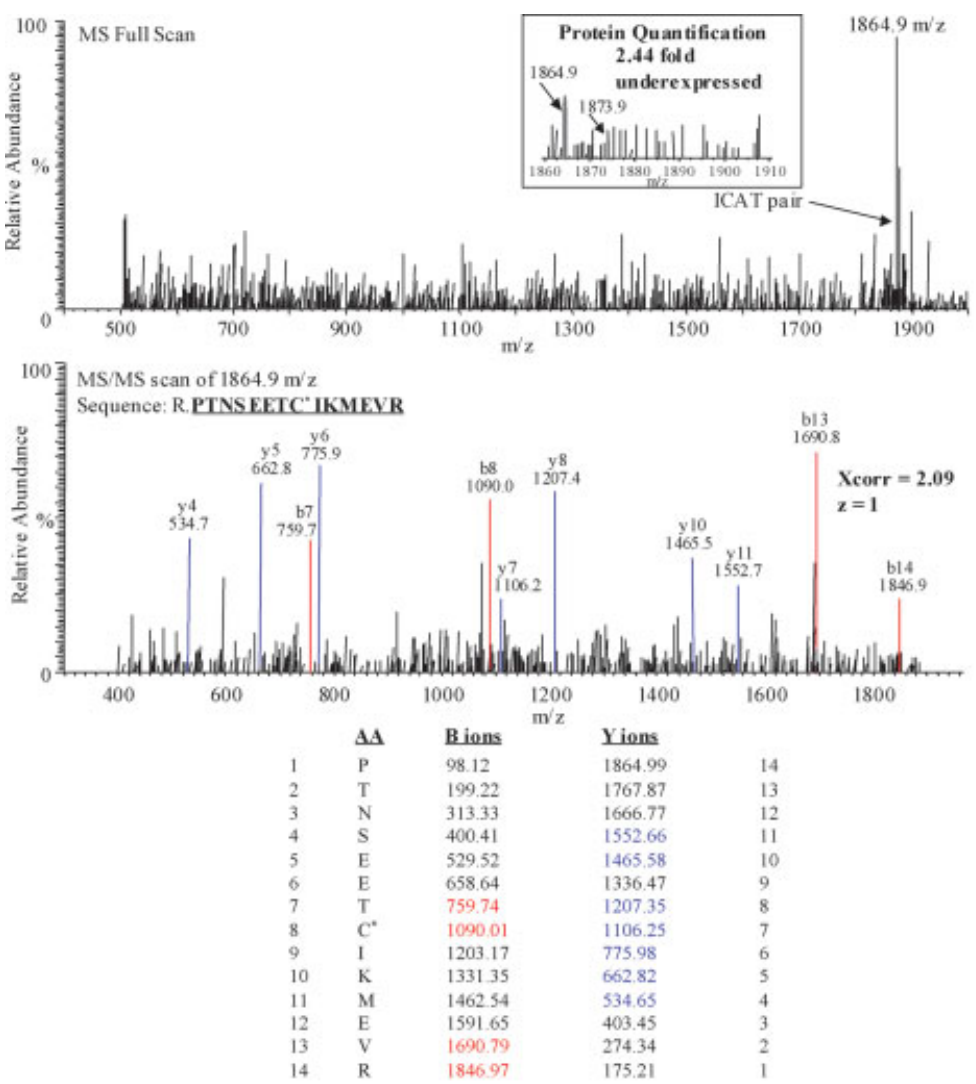

PROTEIN: gi 20178095 - Suppressor of cytokine signaling 4 (SOCS4)

MKKISLKTLRKSFNLNKSKEET DFMVVQQPSLASDFGKDDS.FCSCYGKDMASCDINGEDEKGGKNRSK SELIGTLKRRI SAKOKSKGKAGIPSGSSADEDTFSSSSAPIVFKDVRAQRPIRST S.RSHHYSPAPWPLLRPTNS EETCIKMEVRVKALVHTS

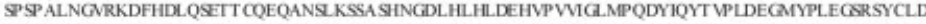
SSSPMEVSAVPPQVGGRAFPEDESOVDQDLVVAPEIFVDQSVNGLLIGTTGMMLQSPRAGHDDVPPLSPLLPPMONNOCOR NFSG T GT EAHVAESMRCHLNFDPNSAPGVARVYDSVQSSGPMVVT SLT EELKKLAKQGWYWGPT RWEAEGKLANYP DGALVRDSSDDRYLLS.SFRSGKTLHTRIEHSV GRFSFYEOPDVEGT SVDLIEHSRDSENGAFCYSR SRLPGSATYPV RLT NPVSRFMQVRSQYLCRFVIRQYTRDLLIQKLPIPNKMKDYLQEKHY
Figure 4. Identification of SOCS4 by LC-MS/MS. MS full scan and data-dependent MS/MS scan showing sequencing of the cICAT tryptic peptide R.PTNSEETC*IKMEVR, which identified SOCS4 as underexpressed 2.44-fold. Peptide sequencing is indicated by matching $b$-ion (red) and $y$-ion (blue) fragments. a protein enzyme USP2, which was identified as being involved in ubiquitin-mediated proteolysis, MAPK signaling, and PPAR signaling.

Analysis of proteins further implicated those involved in JAK/STAT (underexpressed: IL26, CBLC, and SOCS4), WNT (overexpressed: WNT10B; underexpressed: DKK2, NEMO, and RAC3), MAPK (overexpressed: IL1R1, MAP4K1, MAPK14, RASA3, and Rap guanine nucleotide exchange factor (RAPGEF6); underexpressed: NEMO and RAC3), NF$\kappa \mathrm{B}$ (underexpressed: TNFRSF11B and NEMO), and TGF $\beta$ (underexpressed: RPS6KB1 and SMAD5) pathways.

\subsection{Immunoblot validation of differentially expressed proteins}

We selected eight differentially expressed proteins identified by cICAT-LC-MS/MS to validate changes in expression by immunoblot. Importantly, relative differences between cICAT and immunoblot were within $50 \%$ of each other. Immunoblot analysis demonstrated that USP9, ras GTPaseactivating protein 3 (GAP1), PCLN1, and STCN were over- expressed in GA-treated cells relative to control by 5.6-, 2.8-, 2.6-, and 2.1-fold (cICAT), respectively. Proteins that were underexpressed in GA-treated cells including tankyrase, SOCS4, IKKк (NEMO), and OPG were also confirmed by immunoblot analysis and were reduced by 4.2-, 2.4-, 2.4-, and 1.8-fold (cICAT), respectively, relative to control. Figure 6 illustrates the respective overexpressed proteins (left panels) and underexpressed proteins (right panels) with corresponding cICAT and densitometry ratios.

\section{Discussion}

ALK-positive ALCLs are most commonly associated with the $\mathrm{t}(2 ; 5)(\mathrm{p} 23 ; \mathrm{q} 35)$ chromosomal aberration, resulting in expression of the chimeric NPM-ALK oncoprotein [1-3]. Survival of ALK-positive ALCL cells is mediated by the activation of signaling pathways [7-12] that inhibit apoptosis and promote cell proliferation [13]. Vital to the survival of these cells is the function of the chaperone protein Hsp90, which enhances the stability of the NPM-ALK protein [14, 15]. 

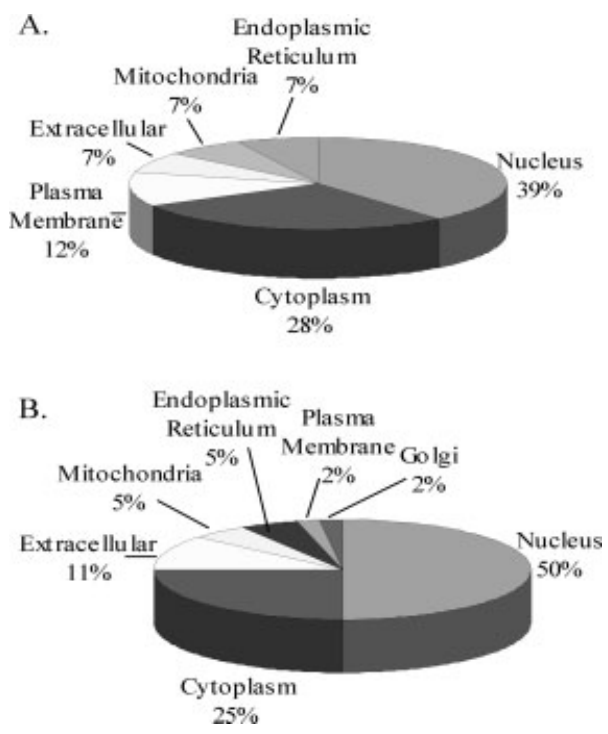

Figure 5. Cellular localization of proteins identified by MS/MS in upregulated $(A)$ and downregulated $(B)$ proteins. Protein from control and cells exposed to $10 \mu \mathrm{M} \mathrm{GA}$ were harvested after $12 \mathrm{~h}$ incubation and cICAT-labeled followed by LC-MS/MS analysis. Peptides were searched against the NCBI database for localization. Proteins overexpressed (A) or underexpressed (B) were categorized by cellular localization.
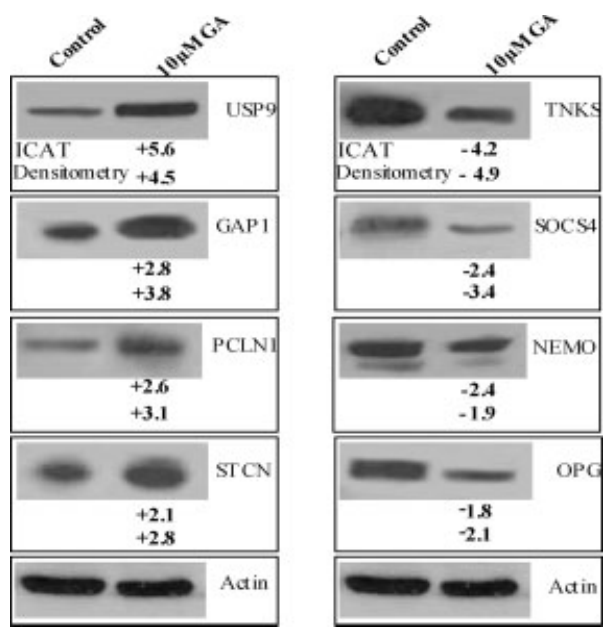

Figure 6. Immunoblot validation of differentially expressed proteins as identified by LC-MS/MS. Total cell lysate was extracted from control and GA-treated cells after $12 \mathrm{~h}$ and proteins separated by SDS-PAGE. Immunoblots were probed with anti-USP9 (1:1000), anti-GAP1 (1:300), anti-PCLN (1:300), anti-STCN (1:300), anti-tankyrase (1:1000), anti-SOCS-4 (1:1000), anti-NEMO (1:1000), anti-OPG (1:500), and anti-actin (1:500). Immunoblots were then incubated at room temperature for $1 \mathrm{~h}$ followed by probing with respective HRP-conjugated secondary antibodies and visualized by chemiluminescence. The left panels depict the overexpressed proteins as identified by LC-MS/MS in control and cells exposed to $10 \mu \mathrm{M} \mathrm{GA}$. The right panels depict the underexpressed proteins as identified in the same samples. Both cICAT- and densitometry fold-change is listed below the $10 \mu \mathrm{M}$ GA lanes. Actin served as a loading control.
Hsp90 assists in the functional maturation of a diverse group of proteins, particularly those involved in cancer-related signaling [16]. GA binds to the N-terminus ATP-binding domain of Hsp90, thereby preventing Hsp90 from performing its chaperone duties [27]. Inhibition of Hsp90 by ansamycins reduces the expression levels of its client proteins by subjecting them to ubiquitin-mediated proteasomal degradation $[14,28]$. GA and its analog, 17-AAG, have been shown to reduce the expression of NPM-ALK and result in subsequent cellular apoptosis $[14,15]$. However, the comprehensive proteomic changes induced by the drug are currently unknown. The results of our quantitative proteomic study demonstrate that the effects of GA on ALK-positive ALCL cells are diverse and affect proteins involved in cell signaling, DNA metabolism, protein metabolism, cell growth, and transport.

In this study, we demonstrate that the NPM-ALK-positive ALCL cell line, SU-DHL-1, is sensitive to GA inhibition of Hsp90. The display of both increased caspase-3 activity (Fig. 2D) and cleavage of PARP (Fig. 3) indicate that Hsp90 inhibition by GA induces the mitochondria-mediated apoptotic pathway, in line with other studies using GA in a variety of cell lines [29-32]. Furthermore, GA treatment resulted in the downregulation of both the native NPM-ALK and phospho-NPM-ALK (Fig. 3), in agreement with previous studies using 17-AAG in ALK-positive ALCL cells [14, 15]. These results reinforce the critical role of NPM-ALK in the survival of these cells $[14,15]$. We further showed that the expression of Hsp90 itself did not change in response to GA treatment (Fig. 3), suggesting that GA does not inhibit expression of Hsp90 [33].

Cell cycle analysis revealed that GA induced $\mathrm{G}_{2} / \mathrm{M}$ cell cycle arrest (Fig. 2B). While this observation contradicts other studies that report $\mathrm{G}_{1}$ arrest in cells exposed to 17-AAG $[14,15]$, GA has been shown to induce $G_{2} / M$ arrest in erythroleukemic cells through inhibition of Cdc2 and induction of $\mathrm{p} 27^{\mathrm{Kip} 1}$ [34] and other $\mathrm{G}_{2} / \mathrm{M}$ regulators [17]. The induction of $\mathrm{p} 27^{\mathrm{Kip} 1}$ but not $\mathrm{p} 21^{\mathrm{Cip} 1}$ (Fig. 3) observed in our studies is consistent with $\mathrm{G}_{2} / \mathrm{M}$ cell cycle arrest.

Analysis of the proteome of GA-treated cells demonstrated that numerous proteins that perform diverse cellular functions are affected by Hsp90 inhibition (Table 1). Proteins known to be involved in signaling pathways important for survival of ALK-positive ALCL cells include PI3K/AKT [8, 9], JAK/STAT [10, 11], and PLC $\gamma$ [7]. Our quantitative proteomic analysis revealed differential expression of proteins belonging to multiple signaling pathways including those in the MAPK (overexpressed: MAP4K1, RASA3, RAPGEF6, MAPK14, and IL1R1; underexpressed: NEMO and RAC3), JAK/STAT (underexpressed: IL26, CBLC, and SOCS4), WNT (overexpressed: WNT10B; underexpressed: RAC3, NEMO, and DKK2), NF-кB (overexpressed: IL1R1; underexpressed: NEMO and TNFRSF11B), and TGF $\beta$ (underexpressed: RPS6KB1 and SMAD5) pathways. Because of the roles of these pathways in survival signaling, we were surprised to identify $41 \%$ overexpressed proteins. However, because 
samples were analyzed after $12 \mathrm{~h}$ drug exposure, these results may be indicative of secondary and tertiary effects of the drug on MAPK signaling. For example, MAP4K1 has been reported to influence FAS-mediated apoptosis and caspase-3-mediated cleavage of MAP4K1 at Asp385 converting MAP4K1 from an activator of the transcription factor NF- $\kappa \mathrm{B}$ into an NF- $\mathrm{\kappa B}$ inhibitor, thus favoring apoptosis [35, 36].

The role of Hsp90 as a molecular chaperone involved in the folding of protein kinases has been well described [18, 37, 38]. Our study also showed that GA treatment resulted in decreased expression of many protein kinases (PTK2B, RPS6KB1, and MAK), including serine/threonine kinases (RPS6KB1 and MAK), and tyrosine kinase (PTK2B) and NPM-ALK. Whether these protein kinases are downstream targets of NPM-ALK and/or client proteins of Hsp90 remains to be determined.

Several Hsp90 client proteins and interactors were found to be differentially expressed by quantitative proteomics and validated by immunoblot analysis, including NPM-ALK, STIP1 [39], NEMO [40], MAK [41], and MCPH1 [42]. Importantly, all of the identified Hsp90 clients and interactors were underexpressed in response to GA, which provides further validation of our results. Moreover, these data suggest that many of the diverse proteins whose expression changed in response to GA may be due to the reduced expression of Hsp90 clients and interactors other than, or in addition to, NPM-ALK. For example, STIP1 has been shown to mediate the association of the Hsp70-client protein complex with Hsp90 [39]. Moreover, the reduced expression of STIP1 may be indicative of incapacitated Hsp90, and could serve as a surrogate marker of disease states in which Hsp90 is overexpressed.

GA inhibits signal transduction by inducing ubiquitination and proteasomal degradation of proteins chaperoned by Hsp90 [16, 20, 43]. Proteins associated with ubiquitin-mediated proteasomal degradation machinery were differentially expressed (overexpressed: PDC, CBLC, PSMD9, USP9X, and PSMD7; underexpressed: PSMD2, CAPN5, and VCIP135). Interestingly, two of the overexpressed proteins (PSMD9 and PSMD7) are non-ATPase members of the $26 \mathrm{~S}$ proteasome. PDC functions in preventing proteins from being degraded and associates with a subunit of the $26 \mathrm{~S}$ proteasome/19S regulatory complex $[44,45]$ suggesting that Hsp90 may regulate the expression of components of the proteasome.

In summary, our studies illustrate the diverse proteins whose expression is changed due to GA inhibition of Hsp90. Importantly, we identified proteins of both known and previously unreported signaling pathways downregulated in response to GA-treatment. We also identified downregulated Hsp90 client proteins and direct interactors as well as upregulation of proteins involved in the 26S proteasome. Our studies illustrate the utility of a proteomics-based approach in the identification and relative quantification of proteins and signaling pathways involved in cancer pathogenesis and the potential for exploitation of new knowledge thereby obtained in approaches to the specifically targeting deranged signaling pathways.
This work was supported by the ARUP Institute for Clinical and Experimental Pathology. Supported in part by the ARUP Institute for Clinical and Experimental Pathology and the Children's Oncology Group Translated Research Award to M. S. L.

\section{References}

[1] Bullrich, F., Morris, S. W., Hummel, M., Pileri, S. et al., Cancer Res. 1994, 54, 2873-2877.

[2] Morris, S. W., Kirstein, M. N., Valentine, M. B., Dittmer, K. G. et al., Science 1994, 263, 1281-1284.

[3] Shiota, M., Nakamura, S., Ichinohasama, R., Abe, M. et al., Blood 1995, 86, 1954-1960.

[4] Borer, R. A., Lehner, C. F., Eppenberger, H. M., Nigg, E. A., Cell 1989, 56, 379-390.

[5] Bischof, D., Pulford, K., Mason, D. Y., Morris, S. W., Mol. Cell Biol. 1997, 17, 2312-2325.

[6] Morris, S. W., Naeve, C., Mathew, P., James, P. L. et al., Oncogene 1997, 14, 2175-2188.

[7] Bai, R. Y., Dieter, P., Peschel, C., Morris, S. W., Duyster, J., Mol. Cell. Biol. 1998, 18, 6951-6961.

[8] Slupianek, A., Skorski, T., Exp. Hematol. 2004, 32, 1265-1271.

[9] Bai, R. Y., Ouyang, T., Miething, C., Morris, S. W. et al., Blood 2000, 96, 4319-4327.

[10] Amin, H. M., Medeiros, L. J., Ma, Y., Feretzaki, M. et al., Oncogene 2003, 22, 5399-5407.

[11] Zamo, A., Chiarle, R., Piva, R., Howes, J. et al., Oncogene 2002, 21, 1038-1047.

[12] Cussac, D., Greenland, C., Roche, S., Bai, R. Y. et al., Blood 2004, 103, 1464-1471.

[13] Hunter, T., Cell 1997, 88, 333-346.

[14] Bonvini, P., Dalla Rosa, H., Vignes, N., Rosolen, A., Cancer Res. 2004, 64, 3256-3264.

[15] Bonvini, P., Gastaldi, T., Falini, B., Rosolen, A., Cancer Res. 2002, 62, 1559-1566.

[16] Neckers, L., Schulte, T. W., Mimnaugh, E., Invest New Drugs 1999, 17, 361-373.

[17] Picard, D., Cell Mol. Life Sci. 2002, 59, 1640-1648.

[18] Galigniana, M. D., Scruggs, J. L., Herrington, J., Welsh, M. J. et al., Mol. Endocrinol. 1998, 12, 1903-1913.

[19] Caplan, A. J., Jackson, S., Smith, D., EMBO Rep. 2003, 4, 126-130.

[20] Neckers, L., Mimnaugh, E., Schulte, T. W., Drug Resist. Updat. 1999, 2, 165-172.

[21] Lin, Z., Crockett, D. K., Jenson, S. D., Lim, M. S., ElenitobaJohnson, K. S., Mol. Cell Proteomics 2004, 3, 820-833.

[22] Lim, M. S., Elenitoba-Johnson, K. S., Lab. Invest 2004, 84, 1227-1244.

[23] Marchal, J. A., Boulaiz, H., Suarez, I., Saniger, E. et al., Invest New Drugs 2004, 22, 379-389.

[24] Piccotti, J. R., LaGattuta, M. S., Knight, S. A., Gonzales, A. J., Bleavins, M. R., Drug Chem. Toxicol. 2005, 28, 117-133.

[25] Gygi, S. P., Rist, B., Gerber, S. A., Turecek, F. et al., Nat. Biotechnol. 1999, 17, 994-999.

[26] Peng, J., Elias, J. E., Thoreen, C. C., Licklider, L. J., Gygi, S. P., J. Proteome Res. 2003, 2, 43-50. 
[27] Grenert, J. P., Sullivan, W. P., Fadden, P., Haystead, T. A. et al., J. Biol. Chem. 1997, 272, 23843-23850.

[28] Takimoto, C. H., Diggikar, S., Hematol. Oncol. Clin. North Am. 2002, 16, 1269-1285.

[29] Castro, J. E., Prada, C. E., Loria, O., Kamal, A. et al., Blood 2005, 7, 2506-2512.

[30] Yun, B. G., Matts, R. L., Exp. Cell. Res. 2005, 307, 212-223.

[31] Kaarniranta, K., Ryhanen, T., Karjalainen, H. M., Lammi, M. J. et al., Neurosci. Lett. 2005, 382, 185-190.

[32] Nomura, M., Nomura, N., Newcomb, E. W., Lukyanov, Y. et al., J. Cell Physiol. 2004, 201, 374-384.

[33] Sittler, A., Lurz, R., Lueder, G., Priller, J. et al., Hum. Mol. Genet. 2001, 10, 1307-1315.

[34] Kim, H. R., Lee, C. H., Choi, Y. H., Kang, H. S., Kim, H. D., IUBMB Life 1999, 48, 425-428.

[35] Chen, Y. R., Meyer, C. F., Ahmed, B., Yao, Z., Tan, T. H., Oncogene 1999, 18, 7370-7377.
[36] Arnold, R., Liou, J., Drexler, H. C., Weiss, A., Kiefer, F., J. Biol. Chem. 2001, 276, 14675-14684.

[37] Kanelakis, K. C., Pratt, W. B., Methods Enzymol. 2003, 364, 159-173.

[38] Morishima, Y., Kanelakis, K. C., Murphy, P. J., Lowe, E. R. et al., J. Biol. Chem. 2003, 278, 48754-48763.

[39] Odunuga, O. O., Longshaw, V. M., Blatch, G. L., Bioessays 2004, 26, 1058-1068.

[40] Chen, G., Cao, P., Goeddel, D. V., Mol. Cell 2002, 9, 401-410.

[41] Miyata, Y., Nishida, E., Mol. Cell Biol. 2004, 24, 4065-4074.

[42] McCarty, M. F., Integr. Cancer Ther. 2004, 3, 349-380.

[43] Vasilevskaya, I. A., O'Dwyer, P. J., Cancer Res. 1999, 59, 3935-3940.

[44] Barhite, S., Thibault, C., Miles, M. F., Biochim. Biophys. Acta 1998, 1402, 95-101.

[45] Flanary, P. L., DiBello, P. R., Estrada, P., Dohlman, H. G., J. Biol. Chem. 2000, 275, 18462-18469. 